\title{
OREOLEPTIS TORRENTICOLA ZLOTY, SINCLAIR AND PRITCHARD (DIPTERA: TABANOMORPHA) DISCOVERED IN A FOURTH-ORDER STREAM OF THE CASCADE MOUNTAINS OF EASTERN WASHINGTON
}

\author{
Timothy D. Hatten ${ }^{1,4}$, Russell Biggam ${ }^{1}$, John Jorgensen ${ }^{2}$, and Paul Anders ${ }^{3}$
}

\begin{abstract}
AвsTRACT.-The recently described Oreoleptis torrenticola Zloty, Sinclair and Pritchard (Diptera: Tabanomorpha), belonging to the monotypic family Oreoleptidae, was previously described from the Northern Rocky Mountains of the USA and Canada. However, as part of a broad, multidisciplinary study by the Yakama Nation, 30 larvae of O. torrenticola were collected at multiple sites within the Twisp River of the Cascade Mountains in Okanogan County, Washington, 2008-2010. This finding represents a substantial range extension for the species.
\end{abstract}

Resumen.-La especie, recientemente descrita, Oreoleptis torrenticola Zloty, Sinclair y Pritchard (Díptero: Tabanomorpha), de la familia monotípica Oreoleptidae, provenía de las Montañas Rocosas del Norte de los Estados Unidos y Canadá. Sin embargo, se colectaronn 30 larvas de O. torrenticola en una gran cantidad de lugares dentro del río Twisp de la cordillera Cascade del Condado de Okanogan, Washington, entre el 2008 y el 2010, como parte de un extenso estudio multidisciplinario realizado por la Nación Yakama. Este hallazgo representa una extensión significativa de las zonas en las que se encuentra esta especie.

Oreoleptis torrenticola Zloty, Sinclair and Pritchard (Diptera: Tabanomorpha) is a recently described species belonging to the monotypic family Oreoleptidae. For a number of years, larvae from this taxon have been identified as Athericidae or Tabanidae. However, the crocheted prolegs of $O$. torrenticola larvae are longer than those of athericids, and $O$. torrenticola has 4 prolegs per segment versus the 2 found on athericids (Zloty et al. 2005, Courtney and Merritt 2008). These characters and others place Oreoleptidae as a sister group to the Athericidae and Tabanidae (Zloty et al. 2005).

With the exception of a gray literature record (Adams et al. 2010), O. torrenticola is known exclusively from the Northern Rocky Mountains of the USA and Canada (Zloty et al. 2005). However, sampling of benthic macroinvertebrates in the Twisp River, Washington, from 2008 through 2010 produced 30 larvae of $O$. torrenticola from multiple sites. The Twisp River is a $45 \mathrm{~km}$ long, fourth-order stream that drains $634.5 \mathrm{~km}^{2}$ (Nelson 2004) of the North Cascade Mountains south of Washington Pass in Okanogan County, Washington (Fig. 1). Hence, this finding represents a significant range extension for the species, showing that O. torrenticola occurs not only in the Northern Rockies but also in the Northern Cascades. Our finding supports that of Adams et al. (2010), who noted the species in the south fork of the Nooksack River in North Cascades National Park, suggesting an even broader distribution for $O$. torrenticola in these mountains.

Six sites were sampled in the Twisp watershed. All sites were in riffle habitat, and they ranged in elevation from $488 \mathrm{~m}$ to $980 \mathrm{~m}$ and spanned a distance of 43.2 river kilometers (Fig. 1). Samples were taken at 3 positions at each site along a single transect perpendicular to the streambank (midchannel, left bank, and right bank). Sampling was generally conducted monthly at each site, although exceptions occurred due to annual differences in site conditions (e.g., snow, water levels, and flood zone), resource availability, and adaptive management goals. For example, a single Hess sample was collected per siteposition per date during 2008, while 3 were taken per site-position per date during 2010. Moreover, sampling during 2008 did not begin until August due to high water, whereas sampling began in May and April during 2009 and 2010, respectively.

\footnotetext{
${ }^{1}$ Invertebrate Ecology Inc., 121 W. Sweet Ave., Moscow, ID 83843.

${ }^{2}$ Yakama Nation, 406 N. 5th Ave. Twisp, WA 98856.

${ }^{3}$ Cramer Fish Sciences, 317 W. 6th St., Suite 204, Moscow, ID 83843.

4E-mail: timhatten@invertebrateecology.com
} 


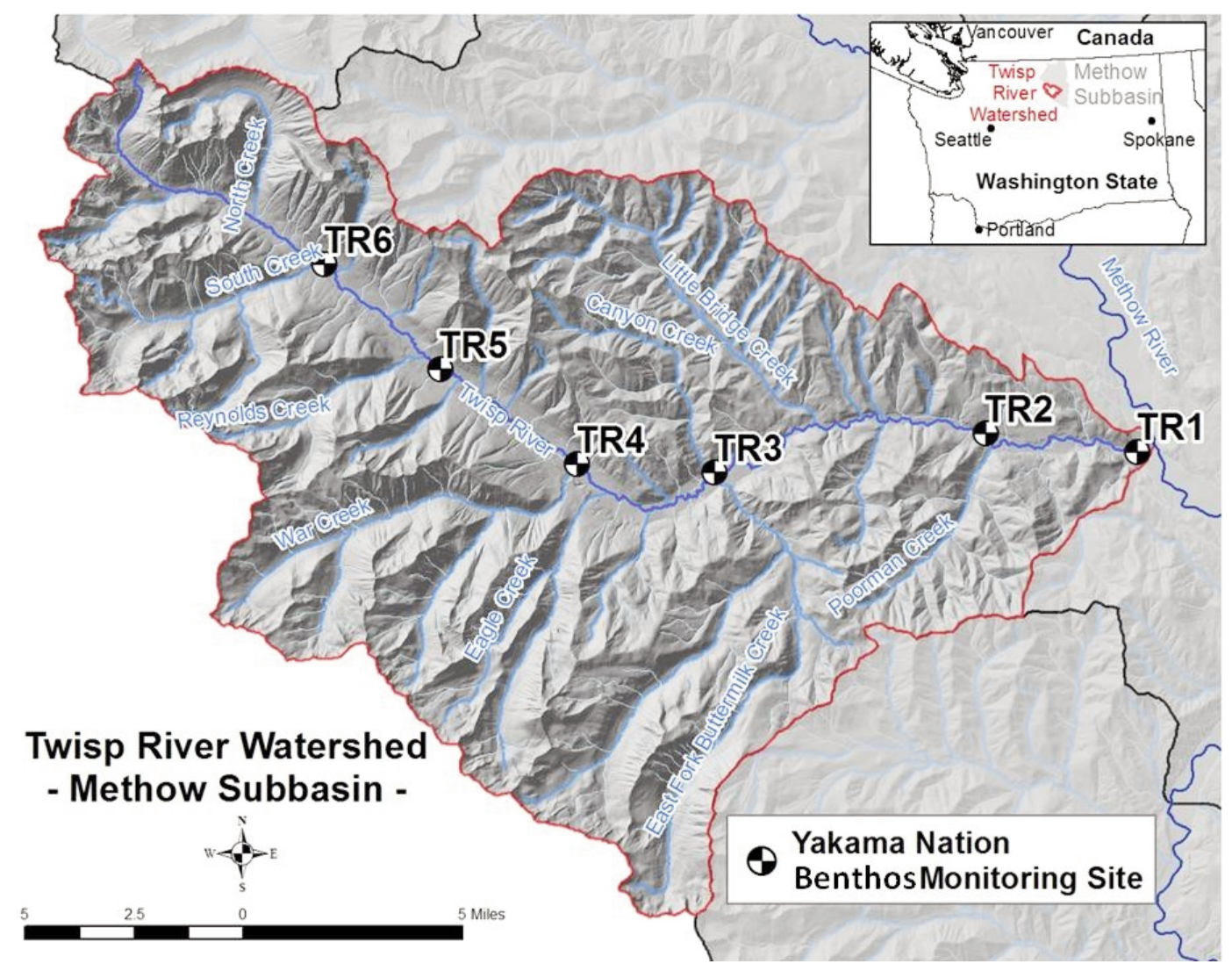

Fig. 1. Map showing benthos monitoring sites in the Twisp River watershed, Okanogan County, Washington. Oreoleptis torrenticola was collected from all sites except TR2 and TR3.

Collections were made by J.J. Jorgensen and K.E. Mott during 2008 and 2009, and by J.J. Jorgensen and J. Schaefer during 2010 (Table 1). Specimens have been deposited in the entomological collection at the University of Calgary; the Ottawa Canadian National Collection; the William F. Barr Museum at the University of Idaho; the Yakama Nation Twisp Field Office in Twisp, Washington; the Orma J. Smith Museum of Natural History in Caldwell, Idaho; and the reference collection of Invertebrate Ecology Inc. in Moscow, Idaho.

Although separated from Rocky Mountain collection sites by a minimum of $400 \mathrm{~km}$ and diverse terrain, occurrence of $O$. torrenticola in the Twisp River is consistent with the known biology of this species, notably adaptation to life in fast-flowing torrential streams (Webb 1994). Oreoleptis torrenticola has a flexible cuticle and low haemocoelic pressure, facilitating movement through small interstitial spaces in gravel and thus survival in the shifting substrates associated with torrential streams (Zloty et al. 2005). Also, O. torrenticola is a voracious predator known to feed on mayflies (Ephemeroptera: Baetidae) (Zloty et al. 2005), a taxon that is plentiful at sampled sites in the watershed.

Benthic macroinvertebrate sampling in the Twisp River is part of a larger, ongoing multidisciplinary study by the Yakama Tribe of Washington to assess nutrient availability, nutrient limitation, and the need for remedial nutrient addition. The project's study design includes pre- and posttreatment biomonitoring of multiple trophic levels to assess pretreatment baseline conditions and posttreatment biological and ecological responses to nutrient addition in this important salmonid stream. It is anticipated that additional $O$. torrenticola specimens may be collected as the study progresses. If a suitable number of individuals are collected, 
TABLE 1. Numbers of Oreoleptis torrenticola captured in benthos samples at 6 sample locations on the Twisp River, Okanogan County, Washington, during 2008-2010.

\begin{tabular}{|c|c|c|c|c|}
\hline Location $^{\mathrm{a}}$ & Elev. $(\mathrm{m})$ & Latitude, longitude & Dates collected ${ }^{\mathrm{b}}$ & Numbers \\
\hline Twisp River (TR1) & 488 & $48^{\circ} 22.061^{\prime} \mathrm{N}, 120^{\circ} 07.235^{\prime} \mathrm{W}$ & & \\
\hline Left bank & & & none & 0 \\
\hline Midchannel & & & NA & 0 \\
\hline Right bank & & & 4 Jun 2009 & 1 \\
\hline Poorman Creek (TR2) & 563 & $48^{\circ} 22.403^{\prime} \mathrm{N}, 120^{\circ} 12.122^{\prime} \mathrm{W}$ & & \\
\hline Left bank & & & none & 0 \\
\hline Midchannel & & & none & 0 \\
\hline Right bank & & & none & 0 \\
\hline Buttermilk Creek (TR3) & 694 & $48^{\circ} 21.814^{\prime} \mathrm{N}, 120^{\circ} 20.309^{\prime} \mathrm{W}$ & & \\
\hline Left bank & & & none & 0 \\
\hline Midchannel & & & none & 0 \\
\hline Right bank & & & none & 0 \\
\hline War Creek (TR4) & 753 & $48^{\circ} 22.102^{\prime} \mathrm{N}, 120^{\circ} 24.207^{\prime} \mathrm{W}$ & & \\
\hline Left bank & & & 21 May, 18 Jun, 15 Jul 2009 & 3 \\
\hline Midchannel & & & 4 Aug 2008; 16 Nov 2010 & 5 \\
\hline Right bank & & & $\begin{array}{l}4 \text { Jun } 2009 ; 19 \text { Jul, } 21 \text { Oct, } \\
16 \text { Nov } 2010\end{array}$ & 10 \\
\hline Mystery Creek (TR5) & 861 & $48^{\circ} 24.082^{\prime} \mathrm{N}, 120^{\circ} 28.235^{\prime} \mathrm{W}$ & & \\
\hline Left bank & & & $\begin{array}{l}29 \text { Sep } 2008 ; 19 \text { Jul, } 18 \text { Aug, } \\
23 \text { Sep, } 16 \text { Nov } 2010\end{array}$ & 5 \\
\hline Midchannel & & & $\begin{array}{l}28 \text { Oct } 2008 ; 15 \text { Jul } 2009 ; \\
14 \text { Apr } 2010\end{array}$ & 4 \\
\hline Right bank & & & none & 0 \\
\hline South Creek (TR6) & 980 & $48^{\circ} 26.301^{\prime} \mathrm{N}, 120^{\circ} 31.921^{\prime} \mathrm{W}$ & & \\
\hline Left bank & & & none & 0 \\
\hline Midchannel & & & 14 Apr, 19 Jul 2010 & 2 \\
\hline Right bank & & & none & 0 \\
\hline
\end{tabular}

asee Fig. 1 for sample locations.

${ }^{b}$ Dates on which $O$. torrenticola specimens were collected.

future analysis could provide additional information regarding the distribution and ecology of $O$. torrenticola and shed light on this rare and little known species.

\section{ACKNOWLEDGMENTS}

This work was funded by a grant from the Yakama Nation, with support from the Bonneville Power Administration. We thank Dr. Frank Zloty for confirming our species identifications.

\section{Literature Cited}

Adams, J., M. Vaughan, and S.H. Black. 2010. Stream bugs as biomonitors: a guide to Pacific Northwest macroinvertebrate monitoring and identification. The Xerces Society, Portland, OR. Available from: http://www.xerces.org/identification-guides-streambugs-as-biomonitors/.
Courtney, G.W., And R.W. Merritt. 2008. Aquatic Diptera. Part One. Larvae of aquatic Diptera. Page 721 (Fig. 22.164) in R.W. Merritt, K.W. Cummins, and M.B. Berg, editors, An introduction to the aquatic insects of North America. Kendall Hunt Publishing Company, Dubuque, IA.

Nelson, M.C. 2004. Movements, habitat use, and mortality of adult fluvial bull trout isolated by seasonal surface flow in the Twisp River, WA. U.S. Fish and Wildlife Service, Leavenworth, WA.

Webb, D.W. 1994. The immature stages of Suragina concinna (Williston) (Diptera: Athericidae). Journal of the Kansas Entomological Society 67:421-425.

Zloty, J., B.J. Sinclair, and G. Pritchard. 2005. Discovered in our backyard: a new genus and species of a new family from the Rocky Mountains of North America (Diptera, Tabanomorpha). Systematic Entomology 30:248-266.

Received 17 March 2012 Accepted 13 February 2013 